\title{
The efficiency of utilization of metabolizable energy and apparent absorption of amino acids in sheep given spring- and autumn-harvested dried grass
}

\author{
BY J. C. MACRAE, J.S. SMITH, P. J. S. DEWEY, A. C. BREWER, \\ D. S. BROWN AND A. WALKER \\ Rowett Research Institute, Bucksburn, Aberdeen AB2 $9 S B$
}

(Received 8 October 1984 - Accepted 27 February 1985)

\begin{abstract}
1. Three experiments were conducted with sheep given spring-harvested dried grass (SHG) and autumn-harvested dried grass (AHG). The first was a calorimetric trial to determine the metabolizable energy (ME) content of each grass and the efficiency with which sheep utilize their extra ME intakes above the maintenance level of intake. The second examined the relative amounts of extra non-ammonia-nitrogen (NAN) and individual amino acids absorbed from the small intestine per unit extra ME intake as the level of feeding was raised from energy equilibrium (M) to approximately $1.5 \mathrm{M}$. The third was a further calorimetric trial to investigate the effect of an abomasal infusion of $30 \mathrm{~g}$ casein $/ \mathrm{d}$ on the efficiency of utilization of $\mathrm{AHG}$.

2. The ME content of the SHG $(11.8 \mathrm{MJ} / \mathrm{kg}$ dry matter (DM)) was higher than that of AHG $(10 \cdot 0 \mathrm{MJ} / \mathrm{kg}$ $\mathrm{DM}$ ). The efficiency of utilization of ME for productive purposes (i.e. above the $\mathrm{M}$ level of intake; $k_{f}$ ) was higher when given SHG $\left(k_{f} 0.54\right.$ between $\mathrm{M}$ and $\left.2 \mathrm{M}\right)$ than when given AHG $\left(k_{f} 0.43\right.$ between M and $\left.2 \mathrm{M}\right)$.

3. As the level of intake of each grass was raised from $M$ to $1.5 \mathrm{M}$ there was a greater increment in the amounts of NAN $(P<0.001)$ and the total amino acid $(P<0.05)$ absorbed from the small intestines when sheep were given the SHG (NAN absorption, SHG $5.4 \mathrm{~g} / \mathrm{d}$, AHG $1.5 \mathrm{~g} / \mathrm{d}$, SED 0.54; total amino acid absorption SHG 31.5 $\mathrm{g} / \mathrm{d}, \mathrm{AHG} 14 \cdot 3 \mathrm{~g} / \mathrm{d}$, SED $5 \cdot 24$ ).

4. Infusion of $30 \mathrm{~g}$ casein/d per abomasum of sheep given $\mathrm{AHG}$ at $\mathrm{M}$ and $1.5 \mathrm{M}$ levels of intake increased $(P<0.05)$ the efficiency of utilization of the herbage from $k_{f} 0.45$ to $k_{f} 0.57$. Consideration is given to the possibility that the higher efficiency of utilization of ME in sheep given SHG may be related to the amounts of extra glucogenic amino acids absorbed from the small intestine which provide extra reducing equivalents (NADPH) and glycerol phosphate necessary for the conversion of acetate into fatty acids.
\end{abstract}

The efficiency of utilization of metabolizable energy (ME) by ruminants is known to be lower for forage diets than for forage plus concentrate or all-concentrate rations (Webster, 1978). It is also known that in the case of all-forage rations the efficiency of utilization can vary with date of harvest. Thus several studies, either growth trials (Lonsdale \& Taylor, 1971) or calorimetric experiments (Corbett et al. 1966; Blaxter et al. 1971; Ribeiro, 1979) have indicated that the nutritive value of dried grass harvested in the spring is superior to that of dried grass harvested from the same pasture in the autumn. As yet no convincing explanation for such differences has been given. One study reported that sheep given spring-harvested grass (SHG) produced more rumen propionate than those given autumnharvested dried grass (AHG) (Beever et al. 1978). However, SHG and AHG prepared in Aberdeen in 1975 showed markedly different efficiencies of utilization of $\mathrm{ME}$ when fed at levels of intake above maintenance (SHG 0.48, AHG 0.30) but there was little indication of differences in the amounts or proportions of the volatile fatty acids (VFA) produced in the rumen (Ribeiro et al. 1981). There was, however, some evidence that the amount of available protein was greater on the SHG. This particular observation (Ribeiro et al. 1981) concerning the $\mathbf{N}$ digestion of sheep given the two grasses harvested at different times of the year has been extended to a further batch of local grass harvested in 1980. A preliminary report of this work has already been communicated (MacRae et al. 1983). 
MATERIALS AND METHODS

Three separate experiments were carried out on dried grasses harvested at the Rowett Research Institute during the spring and autumn of 1980. Expt 1 was a calorimetric trial designed to measure the ME content of the grasses and the efficiency with which sheep utilized their ME intake for maintenance $\left(k_{m}\right)$ and for production $\left(k_{f}\right.$, predominantly fat deposition). Animals were fed at approximately maintenance (M) and $2 \mathrm{M}$ levels of intake. They also had their fasting metabolic rates determined. Expt 2 was designed to measure the amounts of non-ammonia nitrogen (NAN) and individual amino acids entering and leaving the small intestine and to compare the losses of $\mathrm{N}$ either in faeces or urine of sheep given the two grasses at the two levels of intake ( $M$ and 1.5 M). Expt 3 involved infusion of casein into the abomasum of sheep given the autumn-harvested grass to determine whether extra amino acids supplied in this way could increase the efficiency of utilization of the ration.

\section{Grasses}

A sward sown in 1978 with a Scottish Agricultural Industries (Edinburgh) 'HF Blend' mixture of ten parts Lolium perenne $\mathrm{L}$. perennial rye grass (comprising a mixture of early tetraploid, late tetraploid and pasture varieties), three parts Phleum pratense L. cv. Timothy grass and one part Trifolium repens L. white clover was harvested in 1980. In 1980 the sward received a top dressing, on a per acreage basis of 100 units $N, 30$ units $P$ and 60 units $K$ on 3 April. A 'first cut' (i.e. SHG) was taken on 14 June. A further dressing of 50 units $N, 15$ units $P, 30$ units $K$ was applied on 14 June before a second cut was taken in early July (not used for the experiment). A final dressing of 50 units $\mathrm{N}$ was applied on 5 July and a 'third cut' was taken over the period 18-22 August (i.e. AHG).

Each of the experimental herbages was cut with a turbo mower and picked up immediately (i.e. no wilting) with a Pottinger self-filling trailer which cut the grass into $150-250 \mathrm{~mm}$ lengths. It was dried through a low temperature (150-160 $)$ continuous-belt grass dryer without further chopping or cubing and baled for storage before use. At the time of preparing rations each grass was passed through an Atlas hay chopper to produce lengths of approximately $50 \mathrm{~mm}$.

\section{Animals}

Expt 1. Calorimetry. Eight mature Suffolk $\times$ Greyface wethers (live weight $65-76 \mathrm{~kg}$ ) were accustomed to periods of up to $4 \mathrm{~d}$ in a closed-circuit respiration chamber (Wainman \& Blaxter, 1969).

Expt 2. $N$ digestion. Four mature Suffolk $\times$ Greyface wethers (live weight $40-55 \mathrm{~kg}$ ) were each prepared with a rumen cannula (McKenzie \& Kay, 1968) and with simple (' $T$ '-shaped) cannulas at the proximal duodenum and terminal ileum (Hecker, 1974).

Expt 3. Casein infusion. Three mature Suffolk $\times$ Greyface wethers (live weight $45-55 \mathrm{~kg}$ ) were each prepared with abomasal catheters (Ørskov et al. 1979b) and were accustomed to periods of up to $5 \mathrm{~d}$ in a closed-circuit respiration chamber (Wainman \& Blaxter, 1969).

All sheep were housed in metabolism crates and had free access to water at all times. In Expt 1 the animals were offered food twice daily at 08.30 and 16.30 hours. In Expt 2 they received their rations by means of continuous-belt feeders. In Expt 3 they were offered food twice daily at 10.00 and 22.00 hours.

\section{Radioisotopes}

${ }^{103} \mathrm{RuCl}_{3}$ and ${ }^{51} \mathrm{CrEDTA}$ were obtained from Amersham International plc, Amersham, Bucks. The ${ }^{103} \mathrm{RuCl}_{3}$ was converted into ${ }^{103} \mathrm{Ru}$-phenanthroline $\left({ }^{103} \mathrm{Ru}-\mathrm{P}\right)$ (Tan et al. 1971) and the ${ }^{51}$ CrEDTA was diluted with carrier CrEDTA (Binnertts et al. 1968) before administration to the sheep. 


\section{Experimental design}

Expt 1. Calorimetry. The eight sheep were allocated to two groups of four with similar mean fasting metabolic rates (FMR) as determined immediately before the experiment. One group received the SHG at two levels of intake, i.e. sufficient to maintain approximate energy equilibrium (i.e. maintenance level $(\mathbf{M})$ ) and approximately $2 \mathrm{M}$. Two of the animals received the lower intake of the ration first followed by a higher quantity while the other two were fed in the reverse sequence. The other group underwent a similar regimen but were given AHG. All sheep underwent a further FMR measurement at the end of the experiment.

Expt 2. $N$ digestion. Each sheep received both grasses at two levels of intake (approximately $M$ and $1.5 \mathrm{M}$ ) during four periods of 5 weeks duration in a $4 \times 4$ Latin square design. One sheep refused portions of its ration after period 1 (when it had been given SHG at the $M$ level of intake) and was withdrawn from the experiment. In the statistical analysis of the Latin square design, missing value techniques were used to estimate values for the three lost observations.

Expt 3. Casein infusion. Each sheep received AHG at the two levels of intake used in Expt 2 (i.e. $\mathrm{M}$ and $1.5 \mathrm{M}$ ). They were each infused with $30 \mathrm{~g}$ casein/d made up to 1.5 litres with water as described by $\varnothing$ rskov et $a l$. $(1979 b)$ or with water alone at both intake levels for periods of 4 weeks. Sheep nos. 1 and 3 received the infusions and rations in the sequence $\mathrm{M}$ (water), 1.5 M (water), $\mathrm{M}$ (casein), 1.5 $\mathrm{M}$ (casein). Sheep no. 2 underwent the sequence $M$ (casein), 1.5 M (casein), $M$ (water), 1.5 M (water). Animals spent each weekday in the respiration chamber and their $24 \mathrm{~h}$ production measurements $(n 8)$ were determined (Wainman \& Blaxter, 1969) over the last 2 weeks of each period.

\section{Experimental procedures}

Expt 1. Calorimetry. Each measurement period consisted of 3 weeks adjustment to the ration followed by a $7 \mathrm{~d}$ digestibility trial and then a $4 \mathrm{~d}$ confinement in a closed-circuit respiration chamber (Wainman \& Blaxter, 1969). Gaseous exchange and methane production rates were determined over the latter $3 \mathrm{~d}$ of this confinement period. Routine procedures associated with the digestion trial and calorimetric determinations were as described in the First Report of the Feedingstuffs Evaluation Unit (Rowett Research Institute, 1975).

Expt 2. $N$ digestion. Each measurement period consisted of 3 weeks adjustment to the ration followed by a $5 \mathrm{~d}$ digestibility measurement. The sheep then received continuous intraruminal infusions $(500 \mathrm{ml} / \mathrm{d})$ of the dual phase markers ${ }^{103} \mathrm{Ru}-\mathrm{P}(10 \mu \mathrm{Ci} / \mathrm{d})$ and ${ }^{51} \mathrm{CrEDTA}(40 \mu \mathrm{Ci} / \mathrm{d})$ (Tan et al. 1971) for $6 \mathrm{~d}$ before and throughout the period of collection of intestinal digesta.

During the fifth week of each period, four $75 \mathrm{ml}$ samples of duodenal digesta were obtained at $09.00,13.00,17.00$ and 21.00 hours on days 1 and 3 and four $75 \mathrm{ml}$ samples of ileal digesta were obtained on days 2 and 4 . Each of the sets of the diurnal samples were stored separately at $4^{\circ}$ overnight before being mixed on an equal weight basis to give '24-h samples'. On some occasions it was not possible to obtain sufficient ileal digesta on a single day. On these occasions both collections were bulked together to provide one '24 h sample'.

A problem can arise with the calculation of duodenal and ileal flow rates if the rate of infusion of marker is not absolutely constant from day-to-day. In the present study, day-to-day infusion rates were reasonably constant on all but two of the thirteen occasions (coefficient of variation (CV) on day-to-day flow rates $2-4 \%$ ); on two occasions in the first experimental period, both in sheep given the lower levels of SHG and AHG, the CV of day-to-day 'infusion rates' was 6.6 and $6.5 \%$ respectively. Rather than use the infusion rate 
of marker on the day of collection, or the mean for the 2-3 d before and during the collection, it was decided to calculate a 'corrected infusion rate' for each day of collection for sheep in each period from the knowledge of the fractional outflow rate of ${ }^{103} \mathrm{Ru}$ and ${ }^{51} \mathrm{Cr}$ in that particular sheep on that particular intake of food. Fractional outflow rates of each marker were determined at the end of each infusion period from the fall-off of ${ }^{103} \mathrm{Ru}$ and ${ }^{51} \mathrm{Cr}$, counts per g dry matter (DM) and liquid respectively, measured in three hourly faecal samples (Grovum \& Williams, 1973). The faecal samples were collected using the automated device described by McDonald et al. (1979). Infusion rates for each day of collection were then calculated from the equation:

$$
\sum_{i=1}^{4} A_{i} \mathrm{e}^{-m t_{i}} / \sum_{i=1}^{4} \mathrm{e}^{-m t_{i}} .
$$

For the calculation of the 'corrected ${ }^{103} \mathrm{Ru}$ infusion rates', $m$ is the fractional outflow rate (/h) of ${ }^{103} \mathrm{Ru}$ from the rumen of sheep; $A_{1}, A_{2}, A_{3}$ and $A_{4}$ are the actual daily infusion rates of ${ }^{103} \mathrm{Ru}$ on the day of collection, the previous day, $2 \mathrm{~d}$ previous and $3 \mathrm{~d}$ previous respectively, and $t_{1}, t_{2}, t_{3}$ and $t_{4}$ are $0,24,48$ and $72 \mathrm{~h}$ respectively. For infusion rates of $\mathrm{Cr}$ the ${ }^{51} \mathrm{Cr}$ outflow rate was substituted for $m$ and the daily ${ }^{51} \mathrm{Cr}$ infusion rates for $A$ in the same equation.

Expt 3. Casein infusion. Each measurement period consisted of 2 weeks adjustment to level of intake or type of infusion, or both, during which time daily heat production measurements were taken to ascertain that the animals had fully adjusted to their energy expenditures for the new treatment, followed by two $4 \mathrm{~d}$ experimental periods in the respiration chamber where complete energy balance measurements were obtained.

\section{Laboratory procedures}

The Association of Official Analytical Chemists procedures for analysing the feed, faeces and urine from both experiments were as described in the Appendix to the First Report of the Feedingstuffs Evaluation Unit (Rowett Research Institute, 1975). Analyses of the composite samples of duodenal and ileal digesta were as follows: initially, triplicate portions $(2 \mathrm{~g})$ of the $24 \mathrm{~h}$ samples of total digesta and of digesta supernatant fractions (obtained after centrifugation at $12000 \mathrm{~g}$ for $20 \mathrm{~min}$ ) were assayed for their content of ${ }^{103} \mathrm{Ru}$ and ${ }^{51} \mathrm{Cr}$ (using a Tracerlab T-52 scintillation detector; Mechelen, Belgium). Portions of infusate were assayed similarly. These values were used to calculate the 'reconstitution factors' used in the physical mixing of total digesta and supernatant to provide a truly representative sample of digesta according to the procedures of Faichney (1975). The physically reconstituted samples were then used for all subsequent analyses.

Total $\mathrm{N}$ in all samples was determined by a Kjeldahl procedure (Davidson et al. 1970) and ammonia-N was determined by the method of Fawcett \& Scott (1960). The amino acid composition of digesta was determined on hydrolysed samples ( $6 \mathrm{M}$-hydrochloric acid for $18 \mathrm{~h}$ under $\mathrm{N}_{2}$ reflux) using a Chromospek amino acid analyser (Hilger Analytical, Margate, Kent) with a $350 \times 6 \mathrm{~mm}$ ion-exchange column and a gradient borate buffer dilution system.

\section{RESULTS}

The gross chemical composition and energy contents of the two dried grasses are given in Table 1 . The only major difference in the chemical composition of the two grasses was a higher soluble-carbohydrate content and correspondingly lower cell wall carbohydrate content in SHG compared with AHG. The N content of the AHG $(23.2 \mathrm{~g} / \mathrm{kg} \mathrm{DM})$ was slightly higher than that of the SHG $(20.8 \mathrm{~g} / \mathrm{kg})$. 
Table 1. Chemical composition of spring-harvested and autumn-harvested dried grass $(g / k g D M)$

\begin{tabular}{lcc}
\hline \hline & Spring grass & Autumn grass \\
\hline Gross energy (MJ/kg DM) & $18 \cdot 3$ & $18 \cdot 2$ \\
Nitrogen & $20 \cdot 8$ & $23 \cdot 2$ \\
Diethyl-ether extract & 23 & 24 \\
Soluble carbohydrate & 237 & 132 \\
Neutral detergent fibre & 480 & 550 \\
Acid detergent fibre & 260 & 340 \\
\hline \hline
\end{tabular}

DM, dry matter.

\section{Expt 1. Calorimetry}

The digestibility and balance values obtained when each grass was fed to four sheep at two levels of intake (i.e. approximately $\mathrm{M}$ and $2 \mathrm{M}$ ) are given in Table 2 . Where there were no significant differences in variability between treatments the results were analysed as a split-plot design with the effect of grasses compared between sheep and level of feeding within sheep. In Table 2 the significance of the main effects of levels of feeding and type of grass are given; in no case was there a significant interaction. Some variables (urine energy, heat production and $N$ retention) were related to FMR and are adjusted for this by covariance analysis. The ME content of SHG $(11.8 \mathrm{MJ} / \mathrm{kg})$ was higher than that of AHG $(10.0 \mathrm{MJ} / \mathrm{kg})$. This resulted mainly from a lower digestibility $(P<0.001)$ of the AHG; losses of energy as methane were similar between the grasses whilst urine energy losses appeared to be slightly higher $(P<0 \cdot 1)$ for SHG.

The relations between energy retention and energy intake were investigated using the model proposed by Blaxter \& Boyne (1978). They found in eighty calorimetric experiments with sheep and cattle that the retention of energy $\left(E_{R}\right)$ could be related to energy intake $(E I)$ by a generalization of the Mitscherlich equation:

$$
E_{R}=B(1-\exp (-p E I))-1,
$$

when both $E_{R}$ and $E I$ were scaled by dividing by the FMR.

In the present experiment the ME contents of SHG and AHG were different so the scaled ME intake was used in the equation rather than the scaled gross energy used by Blaxter \& Boyne (1978). Furthermore, the FMR of each animal in the trial was measured on three separate occasions spanning 1 year and no significant differences were found either between animals or between times of measurement and therefore the overall mean FMR of 256.4 (SE 4.95$) \mathrm{kJ} / \mathrm{kg}$ live weight $(\mathrm{W})^{0.75}$ was used to represent a common rate for all animals. The equation was then fitted (exactly) to each animal using the approximate $\mathrm{M}$ and $2 \mathrm{M}$ levels of intake, resulting in individual animal estimates of the parameters $B$ and $p$. The values of $B$ and $p$ were found to require a $\log$ transformation before analysis. Their reconverted means and percentage standard errors for each grass were:

$\begin{array}{ccc} & B & p \\ \text { SHG } & 3.27 & 0 \cdot 29 \\ \text { AHG } & 2 \cdot 24 & 0 \cdot 50 \\ \% \text { SE (mean) } & 16.0 & 24 \cdot 7\end{array}$

Although no significant difference exists between the relations for each grass, the curves using the treatment mean values for the two parameters are plotted in Fig. 1 to clarify the 


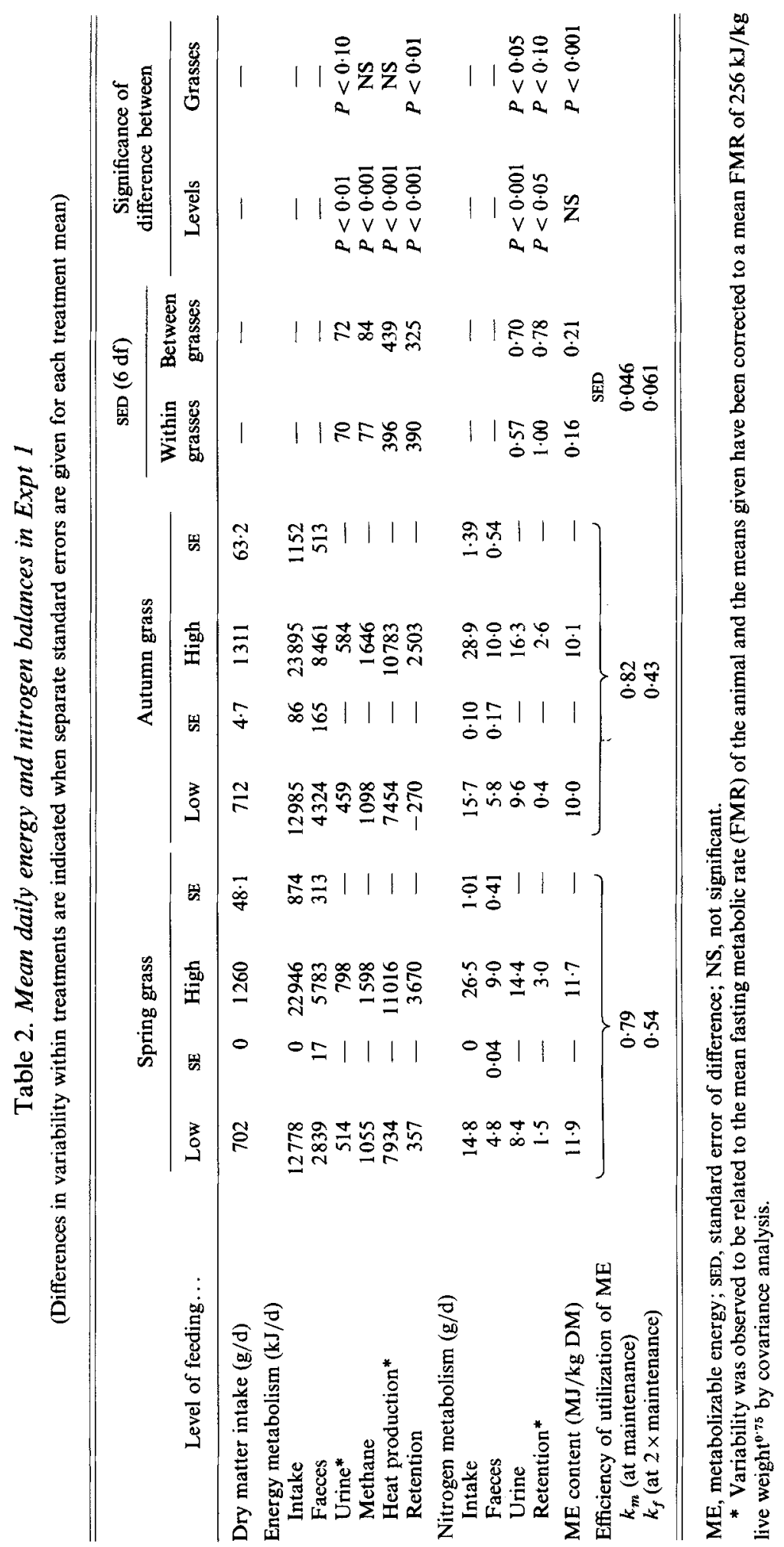




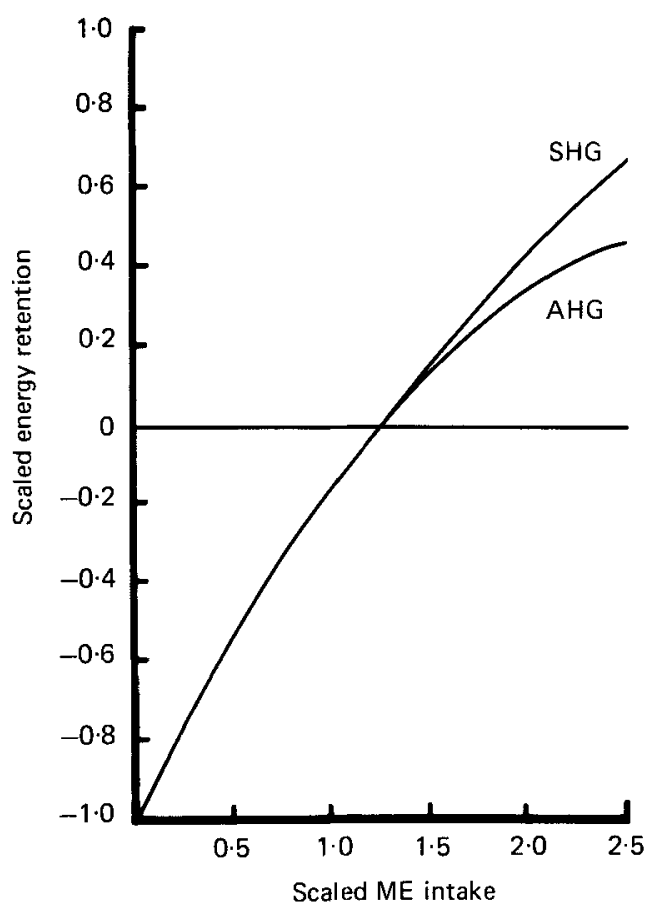

Fig. 1. Relations between scaled energy retention and scaled metabolizable energy (ME) intake in sheep given spring-harvested (SHG) and autumn-harvested (AHG) dried grass (mathematical relations are given in text).

implications. The curves show little difference in the efficiency of utilization of ME below $\mathbf{M}$ (i.e. $k_{m}$ ) but show a possibility of a greater utilization of ME between $\mathbf{M}$ and $2 \mathrm{M}$ for SHG compared with AHG. $k_{m}$ and $k_{f}$ at $2 \mathrm{M}$ were calculated from the curves for each sheep and the treatment means are included in Table 2. Based on the same method the efficiency of utilization of ME between the two levels of intake used in Expt 2 (i.e. $M$ and 1.5 M) would be 0.59 and 0.50 for SHG and AHG respectively.

\section{Expt 2. $N$ Digestion}

As the aim of Expt 2 was to compare the amounts of extra $\mathrm{N}$ absorbed from the small intestine per unit extra ME intake, it was decided that two levels of feeding would be used ( $\mathrm{M}$ and $1.5 \mathrm{M}$ ) and that at both levels the intake of SHG and AHG would be equalized on an ME basis. Because the ME content of SHG $(11.8 \mathrm{MJ} / \mathrm{kg})$ was higher than that of AHG $(10.1 \mathrm{MJ} / \mathrm{kg}$ ) (see Table 2), when the sheep were given similar levels of ME as SHG and AHG their intakes of DM and $\mathrm{N}$ were dissimilar. Levels of intake $\left(\mathrm{g} \mathrm{DM} / \mathrm{kg} \mathrm{W}^{0 \cdot 75}\right)$ of SHG and AHG for individual animals were set at: SHG (M) 27, SHG (1.5 M) 40.5, AHG (M) 35, AHG (1.5 M) 52.5. The amounts of NAN entering and leaving the small intestines on each level of intake of each grass are given in Table 3 but the disparity in $N$ intakes at equal ME intakes for each grass probably negate any straightforward comparison of the NAN and individual amino acid flows at the duodenum and ileum. It is more appropriate to compare the incremental changes which occur when the intake of each herbage was raised from $M$ to $1.5 \mathrm{M}$ (Table 3 ).

The extra amounts of NAN entering the small intestines as the intake of each herbage was raised from M to $1.5 \mathrm{M}$ (SHG $7.2 \mathrm{~g}$, AHG $5.5 \mathrm{~g}$ ) were not significantly different, but 
Table 3. Intakes of dry matter (DM), metabolizable energy $(M E)$ and nitrogen, the amounts of non-ammonia- $N(N A N)$ entering and leaving the small intestine and the amounts of $N$ excreted in faeces and urine and retained by the sheep given spring-and autumn-harvested dried grass at the maintenance $(M)$ and $1.5(M)$ levels of intake

(The incremental $(\Delta)$ changes in these variables when intake of each herbage was raised from $M$ to $1.5 \mathrm{M}$ are given)

\begin{tabular}{|c|c|c|c|c|c|c|c|}
\hline \multirow[b]{2}{*}{ Level of intake... } & \multicolumn{3}{|c|}{ Spring grass } & \multicolumn{3}{|c|}{ Autumn grass } & \multirow{2}{*}{$\begin{array}{l}\text { SED } \\
(3 \mathrm{df})\end{array}$} \\
\hline & $\mathbf{M}$ & & $1.5 \mathrm{M}$ & $\mathbf{M}$ & & $1.5 \mathrm{M}$ & \\
\hline $\begin{array}{l}\text { DM intake }(\mathrm{g} / \mathrm{d}) \\
\Delta \mathrm{DM} \text { intake }(\mathrm{g} / \mathrm{d})\end{array}$ & 481 & 224 & 705 & 620 & 257 & 876 & $\begin{array}{l}43 \cdot 3 \\
56 \cdot 1\end{array}$ \\
\hline $\begin{array}{l}M E \text { intake }(\mathrm{MJ} / \mathrm{d}) \\
\Delta \mathrm{ME} \text { intake }(\mathrm{MJ} / \mathrm{d})\end{array}$ & 5.75 & 2.53 & $8 \cdot 28$ & 6.24 & 2.66 & 8.90 & $\begin{array}{l}0.454 \\
0.604\end{array}$ \\
\hline $\begin{array}{l}N \text { intake }(g / d) \\
\Delta N \text { intake }(g / d)\end{array}$ & $10 \cdot 0$ & 4.9 & 14.9 & $14 \cdot 5$ & $5 \cdot 7$ & $20 \cdot 3$ & $\begin{array}{l}0.90 \\
1.23\end{array}$ \\
\hline 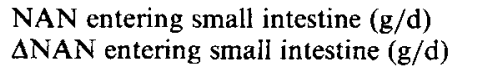 & $12 \cdot 7$ & $7 \cdot 2$ & $19 \cdot 9$ & $16 \cdot 3$ & $5 \cdot 5$ & $21 \cdot 8$ & $\begin{array}{l}0.51 \\
0.70\end{array}$ \\
\hline $\begin{array}{l}\text { NAN leaving small intestine }(\mathrm{g} / \mathrm{d}) \\
\Delta N A N \text { leaving small intestine }(\mathrm{g} / \mathrm{d})\end{array}$ & $4 \cdot 5$ & 1.8 & $6 \cdot 3$ & $5 \cdot 7$ & $4 \cdot 0$ & $9 \cdot 8$ & $\begin{array}{l}0.35 \\
0.48\end{array}$ \\
\hline $\begin{array}{l}\text { NAN apparently absorbed from small } \\
\text { intestine }(\mathrm{g} / \mathrm{d}) \\
\Delta \mathrm{NAN} \text { apparently absorbed from small } \\
\text { intestine }(\mathrm{g} / \mathrm{d}) \\
\text { बNAN apparently absorbed from small } \\
\text { intestine per MJ ME intake } \\
\text { (g/MJ per } \mathrm{g})\end{array}$ & $8 \cdot 2$ & $5 \cdot 4$ & $13 \cdot 5$ & $10 \cdot 6$ & 1.5 & $12 \cdot 1$ & $\begin{array}{l}0.40 \\
0.54\end{array}$ \\
\hline $\begin{array}{l}N \text { excreted in faeces }(g / d) \\
\Delta N \text { excreted in faeces }(g / d)\end{array}$ & $3 \cdot 1$ & $1 \cdot 6$ & $4 \cdot 8$ & $4 \cdot 6$ & $2 \cdot 4$ & $7 \cdot 0$ & $\begin{array}{l}0 \cdot 73 \\
0.99\end{array}$ \\
\hline $\begin{array}{l}\mathrm{N} \text { excreted in urine }(\mathrm{g} / \mathrm{d}) \\
\Delta \mathrm{N} \text { excreted in urine }(\mathrm{g} / \mathrm{d})\end{array}$ & $6 \cdot 5$ & $2 \cdot 0$ & $8 \cdot 6$ & $9 \cdot 9$ & $2 \cdot 3$ & 7.6 & $\begin{array}{l}2 \cdot 48 \\
3 \cdot 22\end{array}$ \\
\hline $\begin{array}{l}N \text { retained }(g / d) \\
\Delta N \text { retained }(g / d)\end{array}$ & 0.3 & $2 \cdot 2$ & $2 \cdot 5$ & 1.8 & $1 \cdot 1$ & $2 \cdot 9$ & $\begin{array}{l}0.85 \\
1.05\end{array}$ \\
\hline
\end{tabular}

the extra amounts of NAN leaving the small intestine on the AHG $(4.0 \mathrm{~g})$ was higher $(P<0.001)$ than on the SHG $(1.8 \mathrm{~g})$. As a result the incremental apparent absorption of NAN per unit ME intake above M on the SHG was three times $(P<0.001)$ that in sheep given the AHG (see Table 3).

All duodenal and ileal samples were analysed for the content of individual amino acids and the amounts of each individual acid entering and leaving the small intestines at each level of intake of both grasses were calculated. Table 4 gives an indication of the amounts of each individual amino acid which were absorbed from the small intestine of sheep given SHG and AHG at intakes of $M$ and $1.5 \mathrm{M}$ together with the net amounts of extra amino acids absorbed as the intake of each herbage was raised from $\mathrm{M}$ to $1.5 \mathrm{M}$. Only in the case of the non-essential amino acid proline was a similar quantity absorbed between the two intakes of each grass. In all other cases, as intake of each grass was raised from $\mathbf{M}$ to $1.5 \mathrm{M}$ there was more extra amino acid absorbed on the SHG diet. The incremental apparent absorption of the essential amino acids histidine, leucine, lysine, phenylalanine and valine and the non-essential amino acids alanine, serine and tyrosine were significantly greater $(P<0.05)$ on the SHG than on the AHG rations. As a result there was over twice as much extra total amino acid $(P<0.05)$ and extra essential amino acid $(P<0.05)$ absorbed as 
Table 4. Amounts of individual amino acids $(\mathrm{g} / 24 \mathrm{~h})$ apparently absorbed from the small intestine of sheep given spring-and autumn-harvested dried grass at the maintenance $(M)$ and $1.5 \mathrm{M}$ levels of intake

(Extra amounts of each amino acid apparently absorbed from the small intestine as intake of each grass was raised from $\mathrm{M}$ to $1.5 \mathrm{M}$ are given)

\begin{tabular}{|c|c|c|c|c|c|c|c|c|}
\hline \multirow[b]{2}{*}{ Level of intake... } & \multicolumn{4}{|c|}{$\begin{array}{l}\text { Apparent absorption from } \\
\text { small intestine } \\
\text { Spring } \quad \text { Autumn }\end{array}$} & \multirow{2}{*}{$\begin{array}{l}\text { SED } \\
(3 \mathrm{df})\end{array}$} & \multicolumn{2}{|c|}{$\begin{array}{l}\text { Extra absorption } \\
\text { as intake raised } \\
\text { from } \mathrm{M} \text { to } 1.5 \mathrm{M}\end{array}$} & \multirow{2}{*}{$\begin{array}{l}\text { SED } \\
(3 \mathrm{df})\end{array}$} \\
\hline & $\mathbf{M}$ & $1.5 \mathrm{M}$ & $\mathbf{M}$ & $1.5 \mathrm{M}$ & & Spring & Autumn & \\
\hline Arginine* & $2 \cdot 2$ & 3.9 & $2 \cdot 6$ & 3.7 & 0.34 & 1.6 & $1 \cdot 1$ & 0.45 \\
\hline Histidine* & 0.9 & 1.6 & $1 \cdot 3$ & $1 \cdot 5$ & 0.03 & 0.7 & 0.2 & 0.03 \\
\hline Isoleucine* & $2 \cdot 5$ & $4 \cdot 3$ & $3 \cdot 1$ & $4 \cdot 1$ & 0.21 & 1.8 & 1.0 & $0 \cdot 27$ \\
\hline Leucine* & 3.9 & $6 \cdot 6$ & $5 \cdot 1$ & $6 \cdot 4$ & $0 \cdot 27$ & $2 \cdot 7$ & $1 \cdot 3$ & 0.34 \\
\hline Lysine* & $2 \cdot 8$ & $5 \cdot 3$ & $4 \cdot 0$ & 5.0 & 0.30 & $2 \cdot 5$ & 1.0 & 0.38 \\
\hline Methionine* & 0.9 & $1 \cdot 3$ & $1 \cdot 2$ & $1 \cdot 3$ & 0.18 & $0 \cdot 4$ & 0.1 & 0.22 \\
\hline Cysteine* & 0.5 & $0 \cdot 7$ & 0.7 & 0.7 & 0.09 & $0 \cdot 2$ & -ve & $0 \cdot 11$ \\
\hline Phenylalanine* & $2 \cdot 6$ & 4.4 & 3.6 & $4 \cdot 2$ & $0 \cdot 16$ & 1.8 & 0.6 & 0.19 \\
\hline Threonine* & $2 \cdot 6$ & $4 \cdot 6$ & $3 \cdot 3$ & $4 \cdot 2$ & $0 \cdot 30$ & $2 \cdot 0$ & $1 \cdot 0$ & 0.39 \\
\hline Valine* & $2 \cdot 7$ & 4.7 & $3 \cdot 5$ & $4 \cdot 5$ & 0.24 & $2 \cdot 0$ & 1.0 & 0.31 \\
\hline Alanine & $3 \cdot 0$ & $5 \cdot 3$ & 3.9 & $5 \cdot 3$ & $0 \cdot 18$ & $2 \cdot 2$ & 1.4 & 0.23 \\
\hline Aspartic acid & 4.8 & $8 \cdot 3$ & $6 \cdot 6$ & 7.9 & 0.87 & 3.6 & $1 \cdot 3$ & 1.09 \\
\hline Glutamic acid & $5 \cdot 2$ & $9 \cdot 1$ & $6 \cdot 4$ & $9 \cdot 0$ & 0.67 & 3.8 & $2 \cdot 6$ & 0.87 \\
\hline Glycine & 2.4 & $4 \cdot 3$ & $3 \cdot 0$ & $4 \cdot 5$ & 0.22 & 1.9 & 1.5 & 0.29 \\
\hline Proline & 1.0 & 3.0 & $2 \cdot 2$ & $4 \cdot 3$ & 0.46 & $2 \cdot 0$ & $2 \cdot 1$ & 0.59 \\
\hline Serine & $2 \cdot 1$ & 3.8 & $2 \cdot 6$ & $3 \cdot 0$ & 0.26 & 1.7 & 0.4 & 0.34 \\
\hline Tyrosine* & $2 \cdot 0$ & $3 \cdot 5$ & $2 \cdot 8$ & $3 \cdot 5$ & 0.15 & $1 \cdot 4$ & 0.7 & $0 \cdot 19$ \\
\hline Total amino acids & $42 \cdot 3$ & 73.9 & $57 \cdot 9$ & $72 \cdot 3$ & $4 \cdot 18$ & $31 \cdot 5$ & $14 \cdot 3$ & $5 \cdot 24$ \\
\hline $\begin{array}{l}\text { Essential } \\
\text { amino acids }\end{array}$ & $21 \cdot 2$ & $36 \cdot 9$ & $27 \cdot 7$ & $35 \cdot 0$ & 1.66 & 15.6 & $7 \cdot 3$ & $2 \cdot 10$ \\
\hline $\begin{array}{l}\text { Non-essential } \\
\text { amino acids }\end{array}$ & $21 \cdot 1$ & $37 \cdot 0$ & $30 \cdot 3$ & $37 \cdot 2$ & - & $15 \cdot 9$ & $7 \cdot 0$ & $3 \cdot 87$ \\
\hline
\end{tabular}

* Amino acids designated as essential for rats (Rose, 1938).

the intake of SHG was raised from $\mathrm{M}$ to $1.5 \mathrm{M}$ compared with the corresponding values found with AHG.

\section{Expt 3. Casein infusion}

The mean daily ME intakes (including the energy contained in the casein infusion where appropriate) and energy expenditures determined when the three sheep consumed $M$ and $1.5 \mathrm{M}$ levels of $\mathrm{AHG}$ with or without infusions of casein are given in Table 5. In each case the infusion of a constant amount of casein at each level of intake resulted in an increase in the calculated efficiency of utilization of the extra ME supplied as AHG. The mean $k_{f}$ of the AGH plus water in this experiment $(0.45)$ was slightly lower than that calculated for this range of intakes from values obtained 2 years earlier in Expt 1 (0.50, see p. 203). However, casein infusion increased the $k_{f}$ from 0.45 to 0.57 , the latter value being similar to the calculated $k_{f}$ of SHG over this range of intake $(0 \cdot 59$, see p. 203$)$.

\section{DISCUSSION}

Although there are several previous reports that the nutritive value of SHG is higher than that of AHG (Corbett et al. 1966; Blaxter et al. 1971; Lonsdale \& Taylor, 1971; Ribeiro, 1979), the causes of these differences have not been identified. Both Corbett et al. (1966) 
Table 5. Energy balance values of sheep given autumn-harvested grass with or without casein infusions at maintenance $(M)$ and $1.5 M$ levels of intake

\begin{tabular}{|c|c|c|c|c|c|c|c|c|}
\hline \multirow[b]{2}{*}{ Level of intake.. } & \multicolumn{3}{|c|}{$\begin{array}{l}\text { Without casein } \\
\text { infusion }\end{array}$} & \multicolumn{3}{|c|}{$\begin{array}{l}\text { With casein } \\
\text { infusion }\end{array}$} & \multirow[b]{2}{*}{ SED } & \\
\hline & M & & $1.5 \mathrm{M}$ & $\mathbf{M}$ & & $1.5 \mathrm{M}$ & & \\
\hline $\begin{array}{l}\text { ME intake }{ }^{\dagger} \\
\Delta \mathrm{ME} \text { intake }\end{array}$ & 6555 & 3499 & 10054 & 7083 & 3673 & 10756 & $\begin{array}{l}135 \\
191\end{array}$ & $\overline{\mathrm{NS}}$ \\
\hline $\begin{array}{l}\text { Heat production } \dagger \\
\Delta \text { Heat production }\end{array}$ & 6658 & 1916 & 8574 & 7054 & 1576 & 8630 & $\begin{array}{l}58 \\
82\end{array}$ & $P<0.02$ \\
\hline Efficiency & & 0.452 & & & 0.568 & & 0.033 & $P<0.05$ \\
\hline
\end{tabular}

ME, metabolizable energy; NS, not significant.

$\dagger$ Values are for comparison of means within infusion types.

and Blaxter et al. (1971) referred to the higher soluble-carbohydrate contents of the SHG (see difference in composition of the present grasses in Table 1) as a possible reason for the difference. Indeed, Beever et al. (1978) reported that the higher content of soluble carbohydrate and lower content of protein in their spring-cut freeze-stored herbage led to a more efficient fermentation in the rumen and a higher yield of total VFA, particularly propionate, when $950 \mathrm{~g} \mathrm{DM} / \mathrm{d}$ of each grass was fed to sheep. They also observed a greater net gain of protein anterior to the duodenum of sheep given the SHG which equalized the amounts of NAN entering the small intestine on each herbage. An earlier report from this laboratory (Ribeiro et al. 1981) suggested that at equal gross energy intakes of SHG and AHG (23 MJ/d) the amount of $N$ entering the small intestine per unit ME intake was higher in sheep given the SHG. Unfortunately both these previous studies suffered from major problems of interpretation. Firstly, each grass was fed at only a single level of intake, equalized on a DM basis in the study of Beever et al. (1978) and on a gross energy basis in the study of Ribeiro et al. (1981). Unfortunately the ME content of SHG was 14-17\% higher than that of AHG in both studies and so the experiments were confounded by unequal ME intakes. Furthermore, efficiency of utilization of ME above $\mathrm{M}\left(k_{f}\right)$ is, by definition, an incremental assessment (i.e. $\Delta E_{R}$ above $\mathrm{M} \div \Delta \mathrm{ME}$ intake above $\mathrm{M}$ ). This being so, comparisons of parameters which might affect $k_{f}$ ought also to be carried out on the same incremental basis. However, when only one intake of each ration is employed such an incremental relation must by necessity be assessed relative to zero ME intake rather than relative to $\mathbf{M}$ intake.

It was for this reason that Expt 2 of the present study was designed specifically to measure the incremental absorption of nitrogenous end-products of digestion per unit extra ME intake above $M$ when sheep consumed equal intakes of $M E$ for each grass. The results given in Tables 3 and 4 indicate that there were major differences between the incremental amounts of NAN and amino-N apparently absorbed from the small intestine per unit extra ME supplied as SHG and AHG between $\mathrm{M}$ and $1.5 \mathrm{M}$; there were three times as much NAN $(P<0.001)$ and twice as much amino-N $(P<0.05)$ absorbed per unit of ME intake in sheep given the extra SHG.

This difference in magnitude, i.e. between the incremental absorption of NAN and amino acid, was associated mainly with the fact that the duodenal and ileal NAN from sheep given SHG and AHG contained different proportions of total amino acids (duodenal digesta SHG 73 (SE 1·1), AHG 75 (SE 1.7); ileal digesta SHG 52 (SE 1.2), AHG 47 (SE 1.4)). 
These proportions for duodenal digesta were slightly higher and for ileal digesta were slightly lower than corresponding values reported for early- and medium-cut dried grasses by Coehlo da Silva et al. (1972) (duodenal 65 (SE 1.4), ileal 59 (SE 2.4)). The ileal values for the present experiment, particularly for AHG, were undoubtedly low, but the values represent a total of twenty-six different samples (two samples/sheep per treatment), many done in duplicate. The consequence of the differential recovery of amino- $\mathrm{N}$ in ileal digesta (SHG $52 \%$, AHG $47 \%$ of NAN) was to reduce the between-diet differences in amino acid absorption.

\section{Amino acid absorption and energy utilization}

The greater incremental absorption of NAN and amino-N in sheep given SHG (Expt 2) was associated with an improved efficiency of utilization of ME (Expt 1) and it is interesting to speculate whether the present results lend support to the recent suggestion that available protein absorbed from the small intestine may have some influence on the efficiency with which ruminants can utilize the VFA which they absorb from the rumen, particularly on forage-based diets (see MacRae \& Lobley, 1982).

The work of Armstrong \& Blaxter $(1957 a, b)$ and Armstrong et al. $(1957,1960,1961)$ seemed to indicate that ruminants cannot utilize acetic acid as efficiently as they can utilize propionic acid or butyric acid. Blaxter (1962) took this observation further and formulated a causal relation between the amounts of acetate produced by the microbial fermentation of different diets and the efficiency of utilization of the ME of these diets by the animal. Unfortunately, when this postulate was later tested in feeding trials with calves (Rook et al. 1963) and lambs (Ørskov \& Allan, $1966 a, b, c$ ), the findings cast doubts on the general applicability of the theory. Later experiments with lambs which were sustained entirely on infusions of mixtures of VFA into the rumen and casein into the abomasum (Ørskov et al. 1979a) seemed to discredit the theory totally, for when the VFA infusion mixture was changed from one having a molar composition of acetate 75 :propionate 15 : butyrate 10 to one of 45:35:20 respectively the efficiency of utilization of ME was unchanged.

Many of the experimental observations can be rationalized if the efficiency of utilization of acetate depends on its conversion to fatty acids and then into triglycerides. These metabolic steps require both reducing equivalents $\left(\mathrm{NADPH}_{2}\right)$ and glycerol phosphate and, where the provision of precursors of these co-factors is adequate-probably mainly from propionate in animals given roughage plus concentrate diets, or from glycogenic animo acids in the 'infusion lambs' which were receiving $23 \%$ of their ME intake as casein-conversion of acetate into fatty acid can proceed and so efficiency of utilization of ME is high. On the other hand, on roughage diets where neither of these two sources of glycolytic intermediates is particularly abundant, the animal may have a problem in clearing the acetate which it absorbs and may need to catabolize the acetate via the TCA cycle plus some form of futile cycle (perhaps acetate $\rightleftharpoons$ acetyl CoA) which will use up the ATP produced by the TCA cycle, thus giving the lower efficiencies of utilization of ME observed on forage diets. In the present study, $\mathrm{N}$ retention values (Table 3 ) and amino-N absorption values (Table 4) would indicate that as the level of energy intake of each ration was raised from $M$ to $1.5 \mathrm{M}$ there was an extra $10.3 \mathrm{~g} / \mathrm{d}$ more amino acid absorbed from the small intestine, but not deposited as retained $\mathrm{N}$ in sheep given the SHG diet. It can be calculated that if this amino acid were to be used as glycolytic precursors (i.e. providing more $\mathrm{NADPH}_{2}$ and glycerol phosphate for converting acetate into depot lipid) it would have the potential to save approximately 110-140 mmol acetate from oxidation depending on the proportion of the $\mathrm{NADPH}_{2}$ derived from the pentose phosphate pathway and from the isocitrate dehydrogenase (ICDH) shuttle (i.e. all the $\mathrm{NADPH}_{2}$ from the pentose phosphate pathway would provide a saving of $110 \mathrm{mmol}$ acetate; $50 \%$ of $\mathrm{NADPH}_{2}$ from the ICDH shuttle would provide a saving of $142 \mathrm{mmol}$ acetate). This would represent a saving of approximately $100-140 \mathrm{~kJ}$ heat $/ 24 \mathrm{~h}$ 
which could account for approximately $40 \%$ of the observed difference in $k_{f}$ between $\mathrm{M}$ and $1.5 \mathrm{M}$.

The study of Beever et al. (1978) indicated that with their spring- and autumn-harvested grasses, sheep given the spring grass absorbed a lower acetate: propionate value (2.55) than did sheep given the autumn grass (3.15). This would provide an alternative means of generating the cofactors needed to convert acetate into depot fat and so increase overall $k_{f}$ of the ration. The present study did not incorporate any attempt to measure the amounts of VFA produced on the SHG and AHG diets. A separate study was started to look at that aspect but had to be stopped because of the very poor values which were obtained; there appeared to be a major problem associated with the mixing of ${ }^{14} \mathrm{C}$-tracer in the rumen of sheep given the grasses and plateau specific activity values exhibited unacceptably high variance ratios (CV 16-57\%; L. A. Bruce, G. E. Lobley and J. C. MacRae, unpublished results). The molar proportions of acetate:propionate:butyrate present in the rumen samples taken at hourly intervals on a number of separate days from sheep given SHG and AHG in that aborted experiment were SHG: acetate $68-72$, propionate 19-22, butyrate 8-12; AHG: acetate 71-74, propionate $18-20$, butyrate $8-10$. The between-day acetate: propionate values ranged from 3.1 to 3.8 in sheep given SHG and from 3.5 to 3.9 in sheep given AHG. Assuming that the relative amounts of each VFA absorbed are proportional to the molar ratios present (Weller et al. 1967) it would appear that the animals given SHG in the present study probably had marginally more propionate available as precursors of NADPH and glycerol phosphate. Nevertheless, the calculations of potential extra NADPH supplied from the extra apparent absorption of amino-N and SHG, and the evidence from Expt 3 that additional casein- $\mathrm{N}$ stimulated an increase in the efficiency of utilization of ME of AHG, do tend to support the theory that the supply of amino acids can influence the efficiency of utilization of ME in sheep given forage rations where the acetate:propionate values are high.

\section{REFERENCES}

Agricultural Research Council (1984). The Nutrient Requirements of Ruminant Livestock, No. 1. Slough: Commonwealth Agricultural Bureau.

Armstrong, D. G. \& Blaxter, K. L. (1957a). British Journal of Nutrition 11, 247--272.

Armstrong, D. G. \& Blaxter, K. L. (1957b). British Journal of Nutrition 11, 413-425.

Armstrong, D. G., Blaxter, K. L. \& Graham, N. McC. (1957). Proceedings of the British Society of Animal Production pp. 3-15.

Armstrong, D. G., Blaxter, K. L. \& Graham, N. McC. (1960). Proceedings of the Nutrition Society 19, xxxi.

Armstrong, D. G., Blaxter, K. L. \& Graham, N. McC. (1961). British Journal of Nutrition 15, $169-175$.

Beever, D. E., Terry, R. A., Cammell, S. B. \& Wallace, A. S. (1978). Journal of Agricultural Science, Cambridge 90, $463-470$.

Binnerts, W. T., van't Klooster, A. Th. \& Frens, A. M. (1968). Veterinary Record 82, 470.

Blaxter, K. L. (1962). The Energy Metabolism of Ruminants. London; Hutchinson.

Blaxter, K. L. \& Boyne, A. W. (1978). Journal of Agricultural Science, Cambridge 90, 47-68.

Blaxter, K. L., Wainman, F. W., Dewey, P. J. S., Davidson, J., Denerley, H. \& Gunn, J. B. (1971). Journal of Agricultural Science, Cambridge 76, 307-319.

Coelho da Silva, J. F., Seeley, R. C., Beever, D. E., Prescott, J. H. D. \& Armstrong, D. G. (1972). British Journal of Nutrition 28, 357-371.

Corbett, J. L., Langlands, J. P., McDonald, I. \& Pullar, J. D. (1966). Animal Production 8, 13-27.

Davidson, J., Mathieson, J. \& Boyne, A. W. (1970). Analyst, London 95, 181-193.

Faichney, G. J. (1975). In Digestion and Metabolism in Ruminants, pp. 277-291 [I. W. McDonald and A. C. I. Warner, editors]. Armidale, Australia: University of New England Publishing Unit.

Fawcett, J. K. \& Scott, J. E. (1960). Journal of Clinical Pathology 13, 156-159.

Grovum, W. L. \& Williams, V. J. (1973). British Journal of Nutrition 30, 313-329.

Hecker, J. F. (1974). In Experimental Surgery on Small Ruminants, p. 126. London: Butterworths.

Lonsdale, C. R. \& Taylor, J. C. (1971). Animal Production 13, 384.

McDonald, J. D., MacRae, J. C. \& McKenzie, J. D. (1979). Laboratory Practice 28, 1317-1318.

McKenzie, J. D. \& Kay, R. N. B. (1968). Journal of Science and Technology 14, 15-16.

MacRae, J. C. \& Lobley, G. E. (1982). Livestock Production Science 9, 447-456. 
MacRae, J. C. \& Reeds, P. J. (1980). In Protein Deposition in Animals, pp. 225-259 [P. J. Buttery and D. B. Lindsey, editors]. London: Butterworths.

MacRae, J. C., Smith, J. S. \& Dewey, P. J. S. (1983). Animal Production 36, 503.

Ørskov, E. R. \& Allen, D. M. (1966a). British Journal of Nutrition 20, 295-305.

Ørskov, E. R. \& Allen, D. M. (1966b). British Journal of Nutrition 20, 509-517.

Ørskov, E. R. \& Allen, D. M. (1966c). British Journal of Nutrition 20, 519-534.

Ørskov, E. R., Grubb, D. A., Smith, J. S., Webster, A. J. F. \& Corrigall, W. (1979a). British Journal of Nutrition 41, 541-551.

Ørskov, E. R., Grubb, D. A., Wenham, G. \& Corrigall, W. (1979b). British Journal of Nutrition 41, $553-558$.

Ribeiro, J. M. C. R. (1979). Digestion and metabolism of forage diets by sheep. PhD Thesis, University of Aberdeen.

Ribeiro, J. M. C. R., MacRae, J. C. \& Webster, A. J. F. (1981). Proceedings of the Nutrition Society 40, 12 A.

Rook, J. A. F., Balch, C. C., Campling, R. C. \& Fisher, L. J. (1963). British Journal of Nutrition 17, $399-406$.

Rose, W. C. (1938). Physiological Reviews 18, 109.

Rowett Research Institute (1975). Feedingstuffs Evaluation Unit First Report. Edinburgh: Department of Agriculture and Fisheries for Scotland.

Storm, E., Brown, D. S. \& Ørskov, E. R. (1983). British Journal of Nutrition 50, 479-485.

Tan, T. N., Weston, R. H. \& Hogan, J. P. (1971). International Journal of Applied Radiation and Isotopes 22, $301-308$.

Wainman, F. W. \& Blaxter, K. L. (1969). In Energy Metabolism of Farm Animals, pp. 429-433 [K. L. Blaxter, J. Kielanowski and G. Thorbek, editors]. Newcastle upon Tyne: Oriel Press.

Webster, A. J. F. (1978). The Management and Diseases of Sheep, pp. 166-174. Slough: Commonwealth Agricultural Bureau.

Weller, R. A., Gray, F. V., Pilgrim, A. F. \& Jones, G. B. (1967). Australian Journal of Agriculture Research 18, 107-118. 